\title{
MIR124-2 Gene
}

National Cancer Institute

\section{Source}

National Cancer Institute. MIR124-2 Gene. NCI Thesaurus. Code C132887.

This gene may be involved in gene expression regulation in neurons. 